\title{
16. ve 20. Yüzyıl İspanyol Romanında Anti-Kahramanın Gelişimi
}

\author{
Yrd. Doç. Dr. Ebru Yener Gökşenli (iD) \\ İstanbul Üniversitesi Edebiyat Fakültesi \\ Ispanyol Dili ve Edebiyatı Ana Bilim Dalı \\ ebruyener@yahoo.co.uk
}

Öz

Bu çalışma, toplumların farklı tarihsel dönemlerinde, savaşlar ve değişen toplumsal koşullar sonucunda edebiyat eserlerine konu olan kahraman imgesinde görülen değişime odaklanır. Çalışmamızın inceleme nesnesi İspanya'nın 16 . ve 20. yüzyıl toplumları, bu dönemlerde gözlemlenen toplumsal farklılaşmalar ve bunların roman yazını üzerindeki etkileridir. Söz konusu yüzyıllarda benzer nedenler sonucunda toplumda benzer sonuçların oluştuğu, bunlara koşut olarak da yazarların edebi eserlerde gerçekçi bir anlatıma yöneldiği tespit edilmiştir. İspanyol edebiyatının 16. ve 20. yüzyıldaki en önemli eserlerinden olan Lazarillo de Tormes, El Quijote, La colmena ve La verdad sobre el caso Savolta romanları antikahramana dönüşen başkişileriyle okura toplumsal eleştiri yüklü bir içerik sunmuştur. Bunu yaparken de önceki yüzyılların trajik, epik ve romantik kahramanlarından farklı olarak başkişilerini ürkek, asosyal ve genellikle "kaybeden" anti-kahramanlar olarak betimledikleri görülür. 16. yüzyılın pikaresk romanının etik dışı anti-kahraman tiplemesi picaro, İspanya'nın ünlü Orta Çağ kahramanı cesur savaşçı Cid'den çok farklıdır. 12. yüzyılda kaleme alındığı düşünülen İspanyol edebiyatının Orta Çağ'dan bugüne kadar korunmuş epik şiiri Mio Cid'deki gibi korkusuz bir kahramana rastlamak 16. yüzyıldan itibaren neredeyse imkânsızlaşır. Çalışmamızda bir yandan İspanya'nın 16. ve 20. yüzyıllar İspanyası detaylı olarak tanımlanırken, öte yandan ele alınan romanlar aracılığıyla kahraman imgesinin anti-kahramana dönüşümündeki koşutluklar, konuyla ilgili kuramlar ve algısal kategoriler ışığında incelenmektedir.

Anahtar Kelimeler: Anti-kahraman, arketip, Lázaro, Quijote, Lukács.

\section{The Antihero in the 16th and 20th Century Spanish Novel}

\section{Abstract}

This study focuses on the changes in the image of the hero portrayed in the literary works, and presents these changes as a result of wars and differentiated social qualities. The main objective of this study is to focus on Spanish society in the 16th and the 20th century, the social changes that were seen in the mentioned period and the effect of theses changes on the composition of Spanish novel. It has been observed that due to similar reasons, similar consequences appeared in Spanish society in the mentioned centuries. As a result of this, novelists tended to use a realistic narrative in their literary works. The most important novels of the 16th and the 20th centuries' Spanish literature Lazarillo de Tormes, El Quijote, La colmena and La verdad sobre el caso Savolta with their protagonists turned into antiheroes 
portrayed a strong negative criticism of the Spanish society. While doing this, they define their protagonists as "loser" antiheroes, as fearful and antisocial ones, on the contrary to the tragic, epic and romantic hero images of the previous centuries. The 16th century's picaresque novel's unethical antihero picaro is quite different from the famous Middle Age's hero: Cid the fearless warrior. It is almost impossible to come across a fearless hero, as it was seen in the first epic castilian poem Mio Cid, assumed to be written in the 12th century and conserved from the Middle Ages until present, after the 16th century. Throughout this study the 16th and 20th centuries Spain has been defined in detail, and the parallelism in the change of the hero's definition between these mentioned centuries has been analyzed in the light of related theories and perceptual categories.

Keywords: Antihero, archetype, Lázaro, Quijote, Lukács. 


\section{GíRIŞ}

Bu çalışmayla İspanyol edebiyatının önemli yapıtlarında yer alan anti-kahraman arketipini $^{1}$ tanımak ve ondan gelişen imgenin simgesel ve toplumsal özelliklerini irdelemek hedeflenmiştir. Farklı yüzyıllar ele alındığında önceleri klasik kahraman özellikleri sergileyen roman başkişilerinin, dönemin farklı toplumsal gerçeklerinin ve yazınsal ihtiyaçlarının bir sonucu olarak zamanla anti-kahramana dönüştüğü görülür. Kahramanın itibarsızlaştırılmasıyla birlikte bu roman kişileri artık epik öykülerdeki gibi ilahi varlıklar olarak değil, birer "kaybeden" olarak tanımlanırlar. Bu çalışmayla amacımız edebi kahramanın yüzyıllar boyunca farklılık gösteren imgesine odaklanmak ve bu değişimi İspanyol romanının 16. ve 20. yüzyıllarda sergilediği birbirine koşut özellikler aracıllğıyla irdelemektir. Yine bu yüzyıllarda diğer dönemlerden farklı olarak anti-kahramanın yıldızının parlamasındaki sosyal nedenler de inceleme konumuzun bir bölümünü oluşturmaktadır.

İspanyol Edebiyatının söz konusu yüzyıllarda kaleme alınmış olan bazı yazınsal örnekleri, kahramanın yaşadığı söz konusu dönüşümün en belirgin göstergeleridir. Çalışmamızda anti-kahramanın yıldızının parladığı 16 . ve 20. yüzyıl romanlarında birbirine koşut bir toplumsal değişimin, buhran ve ahlaki çöküşün izlerine rastlanmıştır. İncelememiz süresince 16. yüzyılın en önemli eserlerinden Miguel de Cervantes'in El Quijote (Don Kişot) romanı ve anonim bir eser olan Lazarillo de Tormes (Lazarillo Hayatı Öğreniyor) adlı roman inceleme nesnemizi oluştururken, 20. yüzyıl İspanyol yazınının iç savaş sonrası roman örneklerinden Camilo José Cela'nın La Colmena (Arı Kovanı) ve 70'li yılların en önemli romanı olarak gösterilen Eduardo Mendoza'nın La verdad sobre el caso Savolta (Savolta davası hakkındaki gerçek) $)^{2}$ isimli eserleri de anti-kahraman imgesini yakından tanımamıza imkân sağlayacaktır. Ancak anti-kahramanın nasıl bir kişi olduğunu anlayabilmek için öncelikle karşıtı olan kahraman imgesini tanımakta yarar vardır.

\section{Arketip ve Edebî İmge Olarak Kahraman/ Anti-Kahraman}

Latincedeki heros sözcügünden gelen kahraman, ünü, erdemleri ve zaferleriyle dikkat çeken, bu özellikleriyle de sıradan insanlardan ayrılan bir varlıktır. Yunan mitolojisine göre kahraman sıradan bir insandan daha fazlasına ancak ilahi varlıklardan da daha azına sahiptir. Yine mitolojiye göre bu özellikleri taşıyan ebeveynlerin çocuğu olduğu için büyük zaferlere imza atması olağandır. Bu yüzden de destanlaşan kahramanlıklarıyla yaşadığı toplumun ona büyük hayranlık duymasına neden olmuştur. Kendisi ölümsüz olmasa da zaman içinde Pollux ve Herkül gibi ölümsüzlük seviyesine ulaşan kahramanlar da mitolojinin konusu kapsamındadır (Chevalier 1988: 558). Epik destanlarda da mitolojide olduğu gibi kahramanların insanları ölümden kurtarması ya da en güçlü düşmanları bile mağlup etmesi olağandır. Amerikalı mitoloji uzmanı ve yazar Joseph Campbell da El héroe de las mil caras (Bin yüzlü kahraman) adlı kitabında (2005) kahramanın savaşçı ve kendi yaşamını riske atan yapısının bir gereklilik ${ }^{3}$ olduğuna değinmiştir: "Kahraman, kendi kişisel ya da yerel geçmişindeki sınırlamalara karşı savaşıp bunları yenme başarısına ulaşmış kişidir. Böylece genel, geçerli ve normal insan formlarına ulaşmıştır" (s. 26).

\footnotetext{
${ }^{1}$ Kültürel öğelerin oluşmasında yapı taşları olan arketipler, bir özelliği ya da fikri içeren ilk örnekler olarak da tanımlanırlar.

2 İncelediğimiz diğer romanlar Türkçeye çevrilmiştir. Ancak Mendoza'nın bu romanının Türkçeye çevirisi bulunmamaktadır.

${ }^{3}$ Toplumsal gerçekçiliği savunan edebiyat kuramcıları Lucien Goldmann ve Georg Lukács da aynı Campbell gibi “kişinin kahraman olarak anılması için bir risk alması gerektiğini" savunur (Aktaran Ignacio Ferreras 1973:25).

SEFAD, 2017 (38): 95-110
} 
Modern roman örneklerine baktığımızda çoğu kahramanın toplumdaki gelişmelere paralel olarak tarihteki epik örneklerine kıyasla farklı değerlerin temsilcilerine dönüştüğünü görürüz. Campbell'ın da belirttiği gibi (2005: 26) "Modern insana göre kahraman ölmüştür ancak sonsuz bir insan olarak yeniden doğmuştur. İkinci işi ve başarısı, yenilediği yaşamı hakkında öğrendiklerini ve aldığı dersleri bizlere aktarmasıdır". Ünlü mitoloji uzmanının bu sözleri farklı yüzyıllardaki okurların kahraman imgesinden farklı beklentiler içinde olduklarına işaret eder. Bundan kahraman imgesinin insanlık tarihi boyunca görülen farklı tasvirlerinin ve toplumsal algılanışının farklılık gösterdiği anlaşılmaktadır. Bunu anlamak için "arketip" ve "imge"nin ne ifade ettiğini kavramakta yarar vardır.

Jung "arketip" ifadesini kolektif bilinçaltındaki birimleri anlatmak için kullanmıştır (Villegas 1978: 48). Kahraman ya da anti-kahraman, edebi eserlerde karşımıza arketipik imgeler olarak çıarken, Villegas imgeyi bir şekilde algılanan ancak yeniden üretilmeye elverişli bir kavram olarak tanımlar (1978: 54). Bu durumda imge, bir nesnenin yeniden üretilmesi anlamına gelmektedir. Wellek ve Warren ise imgenin yeniden şekillenebilen bir kavram oluşunu söyle açıklamıştır: "İmge sözcüğü zihinsel bir yeniden üretme anlamına gelir, geçmiş yaşantılardan sezilerle ilgili, algısal bir anıdır, ancak ille de görsel olması gerekmez" (1959: 320). İşte bu şekilde kahraman imgesi de farklı yazınsal dönemlerde toplumsal ihtiyaçlara göre yeniden şekillenmiştir.

\section{Kuramsal Açıdan Kahraman İmgesi}

Kahraman imgesi hakkında geliştirilen kuramsal yaklaşımlara göz atacak olursak ilk planda imgesel yapısalcılığın kurucusu olan Gilbert Durand karşımıza çıkar. Durand, insanın evrim sürecinden etkilenerek biçimlenen, biyolojik ve kültürel kökenli imge gruplarının varlığını öne sürer. Durand'ın "İmgelem rejimleri” olarak adlandırdığı bu gruplardan ilki gündüz rejimidir. Bunda yükseklik ve düşüş, ışık ve karanlık, üstünlük ve aşağılık ile ilişkili imgeler karşıtlıklar oluşturur. Konumuzu oluşturan kahraman ve antikahraman imgeleri de sergiledikleri karşıtlıkla Durand'ın sözünü ettiği "gece ve gündüz rejimleri" arasındaki yerini alır. Olumlu değerleri saf bir biçimde temsil eden klasik kahramanlar gündüz rejiminin özelliklerini yansıtırlar. Söz konusu konumları, onları "üstün" yapan özelliklere sahip olmayan "ötekiler"in varlığı aracıllğıyla algılanmaktadır (İlgürel 2016: 33-35, 49-51). Bunun aksine, anti-kahramanlar imgelemin gece rejiminde yer alır. Bunlar arasında belirleyici bir unsur olarak "karşıtların diyalektiği" 4 gözlemlenir. Antikahraman roman kişileri, ironik bir bağlamda, klasik kahramanlarınkileri çağrıştıran deneyim ve koşulları ile miskinliklerini, yalnızlıklarını ve zayıflıklarını bir araya getirmektedirler.

Ancak anti-kahraman "kötü adam" olarak algılanmamalıdır. Gaddarlık, acımasızlık, alaycılık, bencillik, bağnazlık, kötümserlik ve toplum değerlerini küçümseme gibi özellikleri kendinde barındırabilen bu yeni kahraman modeli klasik bir kahramanın dürtüleri ile hareket eder. Yine klasik kahramanlar gibi verilen görevleri başarı ile yerine getirebilir ancak bunu yapma yöntemleri daha farklıdır. Bu nedenle okur da kendisini onlarla geleneksel kahramanlarla olduğu gibi tam olarak özdeşleştiremez. Yine de onları tamamen soyutlayıp yok da sayamamaktadır.

\footnotetext{
4 Ünlü Marksist edebiyat kuramcısı Georg Lukács da Durand gibi “karşıtların diyalektiğini” savunmuş ve anlatıda ancak "karşıtların bir arada oluşu ve kimliklerinin sergilenmesi" yoluyla dış dünyanın gerçekliğinin tam olarak algilanabileceğini öne sürmüştür (1970: 28).
} 


\section{Algısal Sınıflandırmaya Göre Kahraman Türleri}

Orta Çağ'ın ya da romantik dönem anlatılarının o bağımsız, meydan okuyan ve her zaman kazanan başkişileri modern anlatılarda mitsel uykularından uyanmış, gerçekçi anlatılar aracılığıyla zayıflıkları ve insani yanlarıyla betimlenerek yansıttıkları toplumsal kesimlerin birer simgesi hâlini almışlardır. Northrop Frye, Anatomy of Criticism: Four Essays (1957) adlı eserinde kahramanı farklı algısal dönemlere göre sınıflandırır. Frye'ın yapısalcı sinıflandırmasına göre bunlar: İlahi ya da yarı ilahi bir özelliğe sahip olan mitsel kahraman (mythic); trajediye, acı çekmeye ve sonunda da kaybetmeye açık olan, insani özellikleriyle de dikkat çeken romantik kahraman (romantic); liderlik özelliği olan, yaşadığı dönemde büyü ya da ilahi güçler bulunmayan ya da bunlara inanmayan, sadece kendine inanan üst öykünsel kahraman (high mimetic); günümüzün anti-kahramanı olarak tanımlanabilecek, okurun sıradan yaşamında karşılaşabileceği sıradan bir kişi olan alt öykünsel (low mimetic) kahraman ve yaşamın kendisine sunduğu tüm sınavlardan hayatta kalma pahasına geçen ironik (ironic) kahramandır.

Konumuz olan modern zamanların anti-kahramanı için Northrop Frye yine aynı eserde bu kahramanın kendinden önce gelen tüm kahraman tanımlarından çok farklı olduğunu, onun amacının sahip olunanı ve var olanı korumak olduğunu öne sürmüştür. Anti-kahramanın başarısızlıkları okurun kendi eksikliklerinin bir yansıması niteliğindeyken, başarıları ise yine tüm insanlığın bir gün kavuşabileceği kazanımlara dair beklenti tohumlarını okurun zihnine ekmektedir.

González Troyano ise (1988) İspanyol edebiyatında kahramanın anti-kahramana dönüşüm evreleri hakkında bir takım tespitte bulunmuştur. Troyano öncelikle Orta Çağ' da kaleme alınmış şövalyelik kökenli morisco ${ }^{5}$ ve soylu sınıfın yer aldığı anlatılara işaret eder. Bunlar Barok dönem edebiyatına denk gelmektedir. Troyano'ya göre bunu, kahraman imgesinin daha sağlamlaştığı, çoğu kez bir ideal için yaşanan ve uğruna trajik bir şekilde ölünen, çoğunlukla da aşk için risk alınan bir kahramanlık dönemi izler; o da romantik dönemdir. Bunun ardından kahramanın kendi ortamını detaylı bir şekilde tanımladığı ve yoğun bir edebi ilgi gördüğü gerçekçi dönem başlar. Sonraki dönemde ise kahramanın yaşadığı değer kaybı ve daha önce hiç görülmedik bir şekilde olumsuz özelliklerle tanımlandığı doğalcı dönem gelmiştir (González Troyano 1988: 40).

\section{ISPANYOL EDEBIYYATINDA SOYLU EPIK KAHRAMANDAN MARJINAL MODERN ANTI-KAHRAMANA}

Eski Yunan ya da Latin tragedyalarındaki kahraman soylu bir kökene sahipti, ancak 19. yüzyıl anlatılarında bu soylu kökenini terk ettiği ve bu değişimle artık topluma örnek olmayacak davranışlarda bulunmaya başladığı görülür. İçine düştüğü ikilemler ise okurların günlük yaşamlarında yaşadıklarına ve çektikleri acılara eşdeğerdir. Kahraman artık kendi değer sisteminin yıkımına da tanıklık eder ve elinden bir şey gelmez.

Edebiyat ve sinema gibi sanatsal üretimlerde karşımıza çıkan anti-kahramanın, geleneksel bir kahramanla karşılaştırıldığında etik dışı özelliklere sahip olduğunu görürüz. Çoğu kez kahramanlıkla sonuçlanan eylemlerin uygulayıcısı olsalar da yöntemleri ve eğilimleri klasik kahraman modeliyle örtüşmez. Güzellik, yakışıklılık, cesaret, bağlılık, dürüstlük, mertlik gibi klasik kahraman imgesinin özelliklerinden payına düşeni çoğu kez almadığı görülür. Oysa bu saydığımız özellikler epik kahramanların vazgeçilmez unsurlarıdır. Örneğin İspanyol edebiyatının korunmuş en eski epik şiiri olan El Cantar de

${ }^{5}$ XV. yüzyılda İspanya' da kalıp Hıristiyanlığı kabul eden Mağriplilere verilen isim. 
Mío Cid'de (Mio Cid'in Türküsü) epik bir kahramanın özelliklerine tam olarak değinilmektedir. ${ }^{6}$ Söz konusu savaşçı; korkusuz, güçlü, "soylu bir sakala sahip" ve "kılıcından korkulan" diye anlatılan bir milli kahramandır. Cid, bu uzun epik şiirde kendi hakkında çıkarılan yalanlara inanan kralın emriyle sürgün edilmiştir. Sevdiklerinden ve kendisine duyulan saygıdan vazgeçmek zorunda bırakılan Cid, erdemleri, savaşçı özellikleri ve gayretleriyle saygınlığını geri kazanır ve krala olan bağlılığını kanıtlar (Benito Lobo 2000: 110). Bu epik kahramanın yaşadığı yıllarda dünyada sürekli savaş ve fetihler gerçekleşirken, olumlu özellikleriyle öne çıkan bu gibi kahramanlar örnek alınacak milli figürler olarak halklara birliktelik duygusu aşılıyorlardı. Bu yönleriyle de edebi ürünlerde sıkça yer verilen bir kahraman modeli oluşturuyorlardı.

Ancak içinde bulunduğumuz modern dönemde mühendislik ve tıp gibi bilim dallarının ilerlemesiyle birlikte insan yaşamı da artık pozitif bilimlere dayanmaya başlamıştır. Campbell, günümüzde her birimizin kahramanın üstlendiği o en zorlu deneyimi paylaştığını söylerken, bunu kabilemizin büyük zafer anlarının parlaklığında değil, onun yerine kişisel umutsuzluk anlarımızda sessizlik içinde yaptığımızın altını çizer (2005: 345). Lukács ve Goldmann'ın da belirttiği gibi sosyal ve ekonomik farklılaşma beraberinde toplumsal değerler sisteminin de yüzyıllar içinde farklılaşmasına neden olmuştur (Aktaran Gonzalez Troyano 1988: 36).

Böylece kanunlara ve içinde yer aldığı toplumun ahlaki değerlerine saygı gösteren epik ya da mitsel kahramanın yerine, zamanla belirli toplum yasalarına inanmayan, onlardaki kusur ya da eksikliklere cevap olarak kendi adalet sistemini uygulayan bir antikahraman belirmiştir.7 Sadece kendi farklı değerler sistemi değil, dış görünüşü ve temsilcisi olan simgeler de değişmiştir. Anti-kahramanımız bir yandan çok zeki olabilirken, öte yandan anti-sosyal, zalim, pasif, sıradan, yersiz işler yapan, dalavereci, çirkin ya da okurda iğrenti hissi yaratan biri olabilmektedir. Genellikle anlatılarda her an hapse girebilecek bir yaşam sürer. Bir anti-kahramanın değerlerinin ve kişiliğinin yaşam yolculuğu içinde değişebildiği de görülür. Bu değişim aldığı bir cezayla ya da yaşadığı bir başarıyla tetiklenebilir. Anti-kahramandaki bu değişim de kahramanın daha önce pek yaşamadığı bir olgudur.

18. yüzyıl sonu ve 19. yüzyıl başından itibaren toplumlardaki değişime paralel olarak edebiyatta da artık ekonomik ve siyasal gelişmelerden beslenen, yalnızca dini doğmaları temel almayan bir anlatı gözlemlenir (Campbell 2005: 341). Nicolás Casariego, Héroes y antihéroes en la literatura (Edebiyatta kahramanlar ve anti-kahramanlar) (2000) başlıklı kitabında, kahramanı "büyük cesaret gerektiren zaferler kazanmış erdemli kişi” olarak tanımlarken, anti-kahramanın ise geleneksel kahramandan görüntüsü ve değerleriyle ayrıldığını öne sürmüştür. Casariego'ya göre bu anti-kahraman kötümser bir gerçekliğin oğludur ve yine dünyanın gerçekçi gözleminin bir sonucudur. Anti-kahraman arzu edilmeyen günümüz dünyasına bir cevap olarak doğmuştur ve gelecekle ilgili hiçbir hedef ya da başarı vaat etmeden yaşar (2000).

Özellikle ele aldığımız İspanyol romanında 20. yüzyılın başlarında aynı 16. yüzyılda olduğu gibi roman kahramanları, mitsel özelliklerinden arınarak anti-kahramanlara dönüştürülmüşlerdir. Özellikle de İspanyol İç Savaş Sonrası romanında görülen bu eğilim

${ }^{6}$ El Cantar de Mío Cid'in 12. yüzyılda yazıldığı düşünülür. Gerçek bir İspanyol kahramanın hikâyesine dayanan bu şiir, İber Yarımadası'nın Mağriplilerden geri alınması sürecinde Cid'in gösterdiği kahramanlığı anlatır.

${ }^{7}$ Edebi bir terim olarak "anti-kahraman", 19. yüzyılda Dostoyevski ile edebiyata girmiştir ve kullanımı 20. yüzyılın ikinci yarısında zirveye ulaşmıştır. 2. Dünya Savaşı'nın ardından 50'li yıllarda post-modern anlatının filizlenmesiyle roman kişilerinde sıkça görülen anti-kahraman imgesi, gerçekçi romanda da yoğun bir biçimde yer almıştır. 
Lukács'ın Roman Kuramı'nda (2007) da savunduğu gibi "olumlu kahraman" öğretisine bir tepki niteliğini almıştır. Aynı değişim, İspanyol edebiyatında 16. yüzyılda kaleme alınan ve modern romanın öncüsü sayılan Miguel de Cervantes'in başyapıtı El Quijote'de de görülür. Biliriz ki bu başyapıt döneme hakim olan şövalyelik romanlarına bir tepki niteliğindedir. Hatta sadece o değil, yine aynı yüzyıla ait, yazarı anonim olarak tanımlanan El Lazarillo de Tormes (Lazarillo Hayatı Öğreniyor) adlı romanda da olumlu kahraman özelliklerinin terk edildiği görülür. Bu ikinci eser 16. yüzyılda ortaya çıkan pikaresk romanın da öncüsü kabul edilir.

\section{İSPANYOL EDEBIYYATINDA İLK ANTİ-KAHRAMAN ÖRNEKLERİ: EL QUIJOTE VE LAZARILLO DE TORMES}

16. yüzyıl İspanyol edebiyatında ortaya çıkan ve kahramanları ilk kez anti-kahraman özelliklerine sahip olan romanlar Lazarillo de Tormes ve El Quijote alışılagelmiş edebiyat örneklerine önemli bir tepki niteliği taşıyordu. Edebiyat tarihinin dönüm noktaları kabul edilen bu iki romana yazıldıkları toplumsal dönem ışı̆̆ında değinmekte yarar vardır.

\section{İspanyol Pikaresk Romanında Bir Anti-Kahraman: Lázaro}

İspanyol edebiyatına baktığımızda yazarı anonim olan Lazarillo de Tormes'de Lázaro gerçek bir anti-kahramandır. Çocuk yaştan itibaren birden çok efendiye hizmet eden Lázaro, roman boyunca öyküsünü hiciv yüklü ancak gerçekçi ve toplumsal eleştiri içeren bir üslupla birinci elden anlatır. İspanyol edebiyatının en önemli yapıtaşlarından olan pikaresk edebiyat, 1554 yılında yayınlanan bu anonim eserle anılır. Bu eser Rönesans'ın yaşandığı 16. yüzyılın ortalarında yayınlanmışır. Bu yıllar modern devlet anlayışının başladığı ve İspanya'nın Amerika kıtasındaki keşifleriyle büyük bir imparatorluğa dönüştüğü dönemdir. İspanya'da kral I. Carlos, V. Carlos olarak Almanya'nın da kralı ilan edilir. Onun hükümdarlığı İspanya için kültürel, entelektüel ve Avrupa'da yeşeren akımlar göz önüne alındığında sanat alanında da önemli bir dışa açılma anlamına gelir. I. Carlos Avrupa'nın tüm halklarını tek bir kraliyet çatısı altında toplamayı hedeflemişse de halkların Protestan ve Katolik olarak ayrılan farklı ideolojileri yüzünden bu hedefine ulaşamaz.

Söz konusu yüzyılın ikinci yarısında ise II. Felipe ile İspanya, Katolikliğin koyu bir savunucusu olarak kendini dış ülkelerden soyutlar. Rönesans'ın İspanya'daki yansımaları gelenekselin modernle buluşması anlamına gelir. Yeni Platonculuk akımının gözde olmasıyla birlikte çoğu yazar betimlemelerinde iç ve dış güzelliği sıklıkla ön plana çıkarır. $\mathrm{Bu}$ kusursuz güzellik betimlemelerinin karşısında ise bazı yazarlar eserlerinde o dönemin toplumsal gerçeklerinden söz etmeyi seçmiştir. O yılların popüler konuları olan carpe diem, beatus ille ve tempus fugit gibi yazarların şekilde ve içerikte mükemmellik peşinde koştukları konulara karşın Lazarillo de Tormes'le pikaresk edebiyat hayata geçer (1554). Abrams hazırladığı sözlükte 16. yüzyıldaki pikaresk edebiyat akımının İspanya'da bu romanla başladığından söz etmektedir (1999: 11). Turner ve Martinez ise Lázaro'yu toplumun içinde olduğu tüm zorluğa rağmen hayatta kalma becerisine sahip bir pikaro olarak tanımlar ve onun sahip olduğu tüm özelliklerle anti-kahraman arketipi olduğunu öne sürer (2003: 15). Alt sosyal tabakadan gelen bir avarenin ilk kez başkarakter olduğu bu roman, Avrupa edebiyatının da ilk modern roman örneği olarak gösterilmiştir (Maiorino 2003: 17).

İdealist roman türünden uzaklaşan bu yeni anlatı biçiminde şu özellikler dikkat çeker: İdeal olanın karşısında gerçekleri yansıtır. Bir dönemin günlük yaşamını aktarır. Olay örgüsü belirli bir mekân ve zamanda geçmektedir. Başkahraman anlatı boyunca psikolojik

SEFAD, 2017 (38): 95-110 
açıdan gelişim sergiler. ${ }^{8}$ Işste tüm bunlar modern romanın özellikleridir. Lazarillo de Tormes ilk kez 1554'de, El Quijote'den tam 50 yıl önce yayınlanmış olsa da kilise karşıtı saldırgan yorumları yüzünden 1559 'da yasaklanmıştır. Eser yazıldığı dönemin İspanyol toplumunun önemli bir bölümünün sosyal durumunu da gözler önüne sermektedir.

16. yüzyıl İspanya'sını tanımlamak gerekirse, birbiri ardına yaptığı savaşlar ve Amerika kıtasının keşfiyle birlikte İspanyol topraklarının bu yüzyılın ortalarında pek çok asker ve sayısız maceraperestle dolup taştığını belirtmek yerinde olacaktır. Bunların çoğu fakir ve işsiz olarak dolaşmaktadır. Bu kişiler zanaatkârlık ve benzeri işler yapmayı da çoğu kez aşağılayıcı görmektedirler. Ne de olsa savaşta tehlikelerin peşinde koşmaya alışkındırlar ve yiyecek bir şeyler bulmak için yaşadıkları küçük maceralar onlar için alınacak önemsiz risklerdir. İspanyol toplumunda görülen bu oluşumun edebiyattaki yansımasında ise picaro ${ }^{9}$ figürü kullanılmıştır. Picaro tiplemesinin öne çıkan özellikleri arasında fırsat kollayan kurnaz yapısı, sadece hayatta kalmak için hırsızlık yapması ve toplumun marjinal kesiminden olması yer alır. Picaro alt bir sosyal sınıfın temsilcisidir ve hikâyenin anlatıcısı olarak kendi yaşam öyküsünü okura aktarır. Bir suçlu potansiyeline sahiptir ya da ufak tefek suçlar işlemiş olabilir. Ancak girdiği sosyal ortamında ıslah olmakta ve toplumda yükselmeyi başarmaktadır. Lázaro da aynı tanıma uygun olarak aç bir şekilde işsiz güçsüz olarak ortalıkta gezinir ve yaşamını daha iyi bir hâle getirmenin yolunu arar. Böylelikle ideallerden yoksun bir anti-kahramana dönüşür. Yaptığı sayısız numaraları okura aktarırken yaşamının belli bir aşamasına kadar olan olayları paylaşır ve bunu yaparken de döneminin politik ve sosyo-ekonomik sorunlarını yalın bir dille ve ustalıkla alaya alır. Okur karşısında kendini her zaman haklı çıkarmaktadır. Lázaro hizmet ettiği farklı sınıflara ait efendilerine sert bir dille getirdiği eleştirilerle her devrin okuruna, o yıllara ait gerçekçi ve eleştirel bir sosyal portre sunar.

Özellikle soylu sınıfı ve din adamlarını eleştiren eser, toplumun ikiyüzlülüğüne, ahlaki ve dini değerlerden yoksun oluşuna değinmektedir: Zalim dilencileri, şefkatten ve ahlaktan yoksun din adamlarını yansıtır. Bir yanda idealize edilmiş şövalyelik, pastoril ve bizans anlatıları kaleme alınırken, diğer yanda dünyanın ilk romanı olduğu ileri sürülen Lazarillo de Tormes duruyordu. Dönemin tüm bu hâkim roman anlayışına meydan okuyan ve gerçekçi yönleriyle dikkat çeken pikaresk roman ise İspanyol gerçekçi romanının başlangıç noktası olarak dikkat çekmiştir. Anlatılan yedi bölüm boyunca Lázaro bir hırsız ve bir çamaşırcının oğlu olarak doğup sonra yetim olarak sürdügü sefil yaşamını anlatır. Babası ölünce annesi onu görme engelli olan ilk efendisine teslim eder. Farklı efendilere hizmet ederek geçirdiği yılların ardından bir hizmetçiyle evlenen ve Toledolu bir rahibin koruması altında ona yardım eden Lázaro, ona da sadık kalmayacaktır. Lázaro'nun yaşadıklarından aldığı dersler ideali yansıtan diğer romanlarda olduğu gibi onu daha dürüst ve doğru birine dönüştürmez. Tüm resmedilen zayıf ve alçakgönüllü olanı aşağılayan ve ezen bir toplumun portresinden ibarettir. Lázaro da pikaro olarak aşağılandığı birçok deneyim yaşar. Peki bu anlatının ortaya çıkmasını teşvik eden unsurlar neler olmuştur? 1492'de İspanya'nın Yeni

\footnotetext{
8 16. yüzyıl İspanya'sında ortaya çıkan pikaresk romandan önce yer alan ve ideal olanı yansıtan anlatılarda, kişiler deneyimlerine koşut olarak herhangi bir gelişim göstermiyorlardı. Ayrıca olay örgüsünün ritmi yavaştı. Ana izlek pek çok yan anlatıyla bölünüyor, anlatıysa belirsiz, gerçek dışı ya da mitsel bir zamanı yansitıyordu. Söz konusu olan fantastik maceraların, karmaşık aşkların ve şövalye maceralarının yer aldığı basite indirgenmiş bir öyküydü. $\mathrm{Bu}$ anlatı her yönden idealize edilmişti.

9 "Picaro"lar, hırsızlar, haydutlar, fahişeler, aylaklar, şendullar, yankesiciler, deliler ve boş gezen maceraperestlerden oluşan alt sınıfın temsilcileridir. 16. yüzyıl İspanya'sı kendilerine Picaro denilen bu insanlarla dolup taşmıştır (Kumrular 2011: 24).
} 
Dünya'yı keşfi ve ülkeye akan zenginlik, kırsal kesimde yaşayan İspanyolları büyük şehirlere göç etmeye yöneltmiştir. Sevilla kenti bir nehir kenti olarak 16. ve 17. yüzyıllarda Yeni Dünya'nın zenginliklerinin en çok aktığı yerdir (Jáuregui Lobera 2007: 170). Bu yüzden Sevilla, pikaro olarak tanımlanabilecek olan hırsızların, yankesicilerin, aylakların, hayat kadınlarının ya da maceraperestlerin doldurduğu bir kente dönüşmüştür. Pikaresk romanlarda da Sevilla kentinin mekân olarak seçilmesine bu yüzden şaşırmamak gerekir.

Pikaresk roman Avrupa ülkelerinde de ilgi görmüştür ${ }^{10}$ ve günümüze kadar az sayıda değişiklikle kaleme alınmaya devam edilmiştir. İspanya'da El Buscón (1626) (Dolandırıcı) ve Guzmán de Alfarache (1599) adlı romanlar da pikaresk edebiyatın önemli örneklerinden olmuşlarsa da, bu alt türün özelliklerini tam olarak yansıtan eserler az sayıdadır. Cervantes'in Novelas Ejemplares (Örnek Alnnacak Hikayeler) (1613) adlı eserinin ve Rinconete y Cortadillo (1613) isimli öyküsünün de pikaresk anlatının önemli birer örneği olduğunu unutmamak gerekir.

\section{İspanyol Edebiyatının Evrensel Anti-Kahramanı: Don Quijote}

İspanyol yazar Miguel de Cervantes'in yaşamının son döneminde kaleme aldığı $E l$ Quijote'de $(1605,1614)$ gerçek bir anti-kahraman bizi karşılar. İki ciltten oluşan eserde söz konusu olan klasik kahramanın psikolojik ve fizyolojik özelliklerinden oldukça uzak, alışılagelmedik bir kahramandır. Ne yakışıklı, ne güçlü, ne kudretli, ne kendine güveni olan, ne yenilmez bir kahraman ya da süper kahraman tiplemesidir. Yazarının Orta Çăg şövalyelik anlatılarını bu eser aracılığıyla alaya almak istemesi nedeniyle Don Quijote bir anti-kahraman olarak düşünülebilir. Başına işler açtığı hayali maceraları onu sonunda evrensel bir anti-kahramana dönüştürür.

Orta Çă̆ toplumu sınıfsal olarak hareketsiz bir yapıya sahiptir. Kim hangi sınıfın üyesi olarak doğduysa öyle devam eder. Ancak hümanizm sonrasında her insanın daha yüksek sınıfların yaşam koşullarına erişebileceği fikri doğmuştur. Don Quijote de "Herkes kendi yaptığı işlerin çocuğudur" sözlerini sarf etmiş ve böylece soylular sistemine getirilecek eleştirilerin de yolunu açmıştır (Benito Lobo 2000: 112). Yine bu dönemde İspanyada soylulardan geçilmemektedir. Ancak bunların arasında fakir olan büyük bir soylu grubu bulunur. Bu fakir soyluların edebiyattaki unutulmaz betimlemeleri de yine Lazarillo de Tormes ve El Quijote'de öne çıkar. Her ikisi de alaycı diliyle toplumsal yapıyı hicvetmiştir. Alonso Quijano, şövalyelik deliliğine kapılmış, üne ve soyluluğa kavuşma tutkusuyla; Lazarillo ise gelişmemiş onur kavramı, aylaklığı ve kendini sefaletten çıkaracak bir iş bekleyişiyle söz konusu duruma unutulmaz iki örnek olmuştur.

Don Quijote o kadar çok şövalyelik romanı okur ki, sonunda kendisi de bir kahramana dönüşmeye karar verir. Aslında bu hayal dünyasında yaşadığı maceralar sayesinde gerçek dünyaya katlanabilmektedir. Bu yönüyle Don Quijote kendi arayışını da biçimlendirir. Böylece insani yanıyla öne çıan bir anti-kahraman figürü olarak okuru karşılar. Değer yargıları kesin olsa da psikolojik sorunları ve düştüğü komik ve saçma olarak tanımlanabilecek durumlarla ve başarısızlıklarıyla okurun ilgisini çeker. ${ }^{11}$

\footnotetext{
${ }_{10}$ İngiltere'den Tom Jones; Amerika'dan Huckleberry Finn'in Maceraları ve Fransa'dan Gil Blas Avrupa Edebiyatı'nın önemli pikaresk örneklerindendir.

11 El Quijote özellikle İngiliz romanına modern romanın ilk örneklerinden olarak ilham vermiştir. Bunu Alman roman yazarları izlemiştir. XIX. yüzyılda Dickens, Melville, Twain, Goethe, Flaubert, Stendhal ve Dostoyevski gibi pek çok yazar tarafından etkilenilen bu ölümsüz eser XX. yüzyıldan itibaren akademik çevrenin üzerinde araştırmalar ve sıkça yorumlar yaptığı bir yapıt olarak göze çarpmaktadır.
}

SEFAD, 2017 (38): 95-110 


\section{YÜZYIL BASSINDA İSPANYA'NIN SOSYO-EKONOMIKK DURUMU VE ANTİ- KAHRAMANIN YENIDEN DOĞUŞU}

1917 yılında İspanya' da resmî olarak Restorasyon krizi baş gösterir. Bu kriz İşçi Genel Birliği'nin (Unión General de los Trabajadores) başlattı̆̆ genel grevle başlar ve bütün işçiler, maden işçileri de dâhil olmak üzere İspanya'da bu greve katılırlar. Bunun ardından greve karşı hükümetin aldığı tedbirler de işe yaramaz ve koalisyonlarla oluşan hükümetlerin sıkça değiştiği bir döneme girilir. Bir yandan İspanya yine bu dönemde büyük bir ekonomik krizin içindedir. 1. Dünya Savaşı'nın bitimiyle ülkede enflasyon yükselmiş, 1918'de görülen ve çok sayıda insanın ölümüyle sonuçlanan "İspanyol gribi" ise zorlu yaşam koşullarını daha da arttırmıştır. İspanya'nın Afrika'da verdiği savaş da hesaba katılırsa söz konusu yıllar ve tabii ki daha sonra gelen iç savaş ve sonrası dönem İspanyol halkını uzun soluklu bir mücadelenin içine sürüklemiştir. Sosyal çalkantıların bu denli yoğun olduğu, ekonomik gerilemenin halkın yaşamsal kaynaklarını sekteye uğrattığı bu uzun tarihsel dönemin etkileri, kaleme alınan edebiyat eserlerine ve onlarda yer alan kişilere de yansımıştır.

Edebiyatta sıkça ortaya çıkan anti-kahramanlar, kendinden önce yer alan romantik akımdaki o kendini tehlikeye atan ve özellikle aşk uğruna türlü mücadelelere girişen kahramanlara benzemez. Gerçekçi ya da doğalcı romanın anti-kahramanları artık birer "kaybeden" olarak okurun karşısına çıkar. Bu durum 16. yüzyıldaki benzerlerini andırır. Özellikle iç savaş sonrasında toplumun içinde bulunduğu ekonomik ve ahlaki çöküş, 20. yüzyılın ikinci yarısına doğru roman başkişilerinin kendilerini yeniden anti-kahraman olarak bulmasına yol açmıştır. İspanyol edebiyatının 16. ve 20. yüzyıllarda okura sunduğu eserler, kahramanın ideallikten uzak özellikleri ve bireyi yaşadığı topluma yönelik getirdiği eleştiri yönünden birbirine koşut içerikler sunmaktadır. Şimdi 20. yüzyılın İspanyol Edebiyatında yer alan ve yüzyılın farklı dönemlerine ait iki anti-kahraman örneğini tanıyalım:

\section{La Colmena ve Martín Marco}

19. yüzyılda İspanyol edebiyatında güçlü etkisiyle karşılaştığımız gerçekçilik akımı, 20. yüzyılın başlarında Fransız kökenli doğalcılık akımının ortaya çıkmasıyla bir süre için zayıfladıysa da yüzyıl ortalarında yeniden canlanır. Özellikle İspanya İç Savaşı sonrasında Camilo José Cela'nın Türkçeye Arı Kovanı olarak çevrilen La Colmena adlı romanı büyük ilgi görür. Nobel Edebiyat Ödülü sahibi Cela, bu romanındaki Martin Marco başkişisiyle o dönemin İspanyol toplumunda işsiz, aç, yalnız ve sevgisiz hâlde yaşam mücadelesi veren büyük kitleleri okura aktarır.

Yazarın iç savaş sonrası İspanyol toplumunu resmettiği Arı Kovanı'nda toplumun en marjinal kesimlerine de yer verilir. Yaşanan şartlar çoğu toplumsal sınıfı savaş sonrasında açlık, işsizlik ve soğuğun etkisiyle zor duruma düşürmüştür. Romanda marjinal bir yaşam süren ancak okumuş olduğu ve şiirle ilgilendiği bilinen Martín Marco, ezilenlerin ve savaş sonrasının kolektif bilincinin sesi konumundadır. Genel anlamda yaşanan ekonomik ve idari sorunları eleştiren bir dış sestir. Onun ağzından aktarılan toplum ve düzene karşı getirilen eleştiriler, aynı zamanda bireyin varoluşçu özlemlerinin de bir yansıması olarak tanımlanabilir. Ancak Martín, çevresi tarafından kimi zaman aşağılanan ve ezilen bir roman başkişisidir. Kahve sahibi Doña Rosa, işçi sınıfının temsilcisi olan çalışanlarına ve müzisyenlere hadlerini bildirdiği gibi, parasını ödeyemeyen Martín Marco'yu da aşağılar. Roman boyunca orta sınıfın iç savaş sonrasındaki düşünce sisteminin, eğer hasta değilse 
sevinmek, karnı da doyuyorsa hâline şükretmek olduğu sürekli olarak okura aktarılır. ${ }^{12}$ Örneğin romanın başlarında Martín Marco, bir sokağın girişindeki parmaklıklara yaslanıp dört tane kestaneyle karnını doyurmaya çalışır (s. 73).

Gerçek bir anti-kahraman özelliği sergileyen Martín Marco romanın çoğu yerinde açlığıyla dikkat çeker (Serra Martinez-Oton Sobrino 1986: 158). Karnını doyurmak için sıkça ablasına gider. Ablası arada bir kardeşine cep harçlı̆̆ı da vermektedir. Romanın dördüncü bölümünde yer alan şu sözler Martín'in açlığını en iyi şekilde anlatır: “(...) bacakları titremektedir, karnı teli kopmuş bir müzikli kutu gibidir (...)"(Cela [t.y.]: 215). Genç adamın sadece açlık değil ısınmayla ilgili de ciddi sorunları vardır. Isınmak için Doña Jesusa'nın randevuevine gider. Doña Jesusa ise ona kıyamayıp, ona ssınmak için Pura adındaki genç çalışanıyla aynı yatağı paylaşmasını önerecektir. Romanda iki “kaybeden” olarak okura aktarılan Martín ve Pura'nın paltolarını da yatağın üstüne atarak donmamak için sırt sırta verip ısındıkları bölüm iç savaş sonrasının ilk dönemindeki İspanyanın bir portresi niteliğindedir (Cela [t.y.]: 222-223). Yazar toplumda tutunamamış ve gerçek sevgiden mahrum olan Pura ve Martín'in ssınmak için bir araya gelişlerini onlara duyduğu acıma ve şefkat duygusuyla betimlemiştir (Serra Martinez- Oton Sobrino 1986: 163). Anlatıcıya göre yeni evli bir çift gibi görünmektedirler.

Martín Marco'nun anti-kahraman özelliklerinin başında aşağılanması, açlığı ve yalnızlığı vardır. Onun ne kadar yalnız ve sevgisiz bir insan olduğu soğuktan donmamak için Pura'ya yanaştığı sahne anlatıcı tarafından betimlenmiştir: "Sevgi olmayınca sıcaklık aramak gerekir" (Cela [t.y.]: 223). Bu başkişinin bir diğer anti-kahraman özelliği ise klasik kahraman imgesiyle ters düşen korkaklığıdır. Meslek olarak yazar olan sol görüşlü bu genç adam kendisini yıllar sonra tanıyan ve ona adıyla seslenen Nati karşısında oldukça ürkek bir şekilde tanımlanır: "Martin, kıza ürkek ürkek baktı. Martín kendisine pek yabancı gelmeyen ama tanıyamadığı bütün yüzlere biraz korkuyla bakar. Üstüne yürüyüp tatsız şeyler söylemeye başlayacaklarını düşünür hep; daha iyi beslenebilseydi böyle düşünmezdi herhâlde" (s. 155).

Martín'in ürkek duruşuyla ilgili bir diğer bölümde ise, genç adam gecenin bir vakti yolda kendisinden belgelerini göstermesini isteyen polise belgelerini evde unuttuğunu söyler. Anlatıcı tarafından, korku içinde, yalvararak, hızlı hızlı konuşan Martín'in konuşurken titrediği bildirilir (s. 213). Martín'in yaşadığı korku, İspanya İç Savaşı sonrasında kendisi gibi pek çok Cumhuriyet destekçisinin yaşadığı korku ve endişenin yansımasıdır.

Martín, anlatının sonunda okura değişime dair bazı düşüncelerini aktarır. Annesinin mezarını ziyarete gitmiştir ve orada kendi kendine: "Artık yaşamımı düzene sokacağım. [...] İyi bir memurluğa hayır demem. Bir süre sonra, hele bina iyi ısınıyorsa, insan bir şeyler bile yazabilir boş zamanlarında. [...] Sosyal Yardım Enstitüsü de fena değil, ama orada bir iş bulmak pek kolay olmamalı. Bu tür işler, bir bankada çalışmaktan çok daha iyidir" der (s. 301). Martín, artık değişme ve bir iş bulma niyetindedir, ancak polis tarafından arandığından da habersizdir. Elinde tuttuğu gazetenin her köşesini okumuş olsa da, daha ilanlar, bildiriler

12 Anlatıı, Don Jaime Arce'nin Kahve'de otururken aklına değişik düşüncelerin takıldığından söz eder. Bunlardan
birisi de Kahve'deki veremli oranıdır. Enerji kaynakları ve yetersiz beslenme, kuşkusuz hastalıkları da beraberinde
getirir. Ancak anlatıcı Kahve' deki veremli oranını da parantez içinde yüzde 10 olarak aktarır (s. 56). Bu orana göre
orada oturan on kişiden biri veremlidir. Bu da hasta nüfus açısından oldukça yüksek bir orandır. SEFAD, 2017 (38): 95-110 
ve Madrid'in çevresinde yaşayanlara verilecek yiyecek karneleri bölümünü okumamıştır (s. 303). Onun değişime dair planlarının gerçekleşip gerçekleşmeyeceği belirsiz kalacaktır. ${ }^{13}$

\section{La verdad sobre el caso Savolta ve Javier Miranda}

Eduardo Mendoza tarafından 1975 yılında yayınlanan ve 70'lerin en önemli İspanyol romanı olarak kabul edilen (Serra Martínez-Oton Sobrino 1986: 192) La verdad sobre el caso Savolta (Savolta davası hakkındaki gerçek) adlı roman 1. Dünya Savaşı'nı takip eden yılların Barselona şehrini ve orada yaşayan farklı sınıfları betimler. Bu şehrin karmaşık ortamına iş bulmak için gelen Javier Miranda yıllar sonra başından geçenleri hatırlar. Savolta silah fabrikasının olayların merkezinde olduğu ve okura pek çok sosyal sınıfın farklı kişiler aracılığıyla resmedildiği bu anlatıda Mendoza okura casus romanı, tarihi roman, tefrika roman ve sosyal roman gibi farklı türleri bir arada sunmaktadır. Eser farklı açılardan eleştirmenler tarafından Chandler ve Hammett'ın polisiye romanlarına, 16. yüzyılın pikaresk romanına, bir yandan da İspanyol edebiyatının ünlü yazarlarından Valle-Inclán ve Baroja'nın yazınsal üslubuna benzetilmiştir (Pérez-Rasilla-Bayo 1990: 286). Yazar, parodi yüklü diliyle çoğu kez mizahi bir anlatının kapılarını aralamış, kullandığı kolaj yöntemi gibi farklı anlatı teknikleriyle de çok yönlü ve zengin bir anlatıya imza atmıştır. Ancak yazar bizi bu romanda İspanya'nın 20. yüzyıl başlarındaki, özellikle 1. Dünya Savaşı'nı takip eden ylllara götürmesiyle tarihsel ve sosyolojik anlamda önemli bilgiler de vermektedir.

Söz konusu ortamda eserin başkişisi ve anlatıcısı olan Javier Miranda iş bulmak ve iyi bir yaşama kavuşmak için Valladolid'den Barselona'ya gelen bir gençtir. Tüm anlatı boyunca olayları onun bakış açısından görürüz ve Miranda herhangi bir ideolojiyi savunmadığı için tüm roman kişilerine aynı mesafede durmaktadır. Tam belirgin olmayan ve çelişkili kişiliğiyle farklı toplumsal sınıflar arasında gezinir ve okur için bu sınıfların izlenebileceği bir köprü niteliği taşır (Alonso 1988: 42). Kimse hakkında ön yargı taşımayan Miranda, bir anti-kahraman olarak eser boyunca hoş olmayan işler yapsa da yine de herkes için birleştirici yollar aramaktan vazgeçmez. Miranda aslında iyi kalpli ve samimi bir kişiliğe sahiptir ancak önüne sunulan gerçeği değiştirmek için de bir şey yapmaz, pasif konumdadır.

Javier Miranda da bir anti-kahraman olarak kendini çoğu kez "bir gemide boğuluyormuş gibi" ve çıkışı olmayan bir yoldaymış gibi hisseder. Önceki sayfalarda ele aldığımız diğer anti-kahraman örneklerine benzer bir şekilde Miranda da yaşadığı yalnızlık hissi ve ruhsal buhranla okura sunulur: "Yalnızlığın günden güne, saatten saate, dakikadan dakikaya daha da ağırlaştığı depresif bir ruh hâline gömülüyorum. (...) Ciddi bir şekilde düşündüm intiharl, ama yeniden düşündüm, var olmaya tutunduğum için değil daha çok korkak olduğum için" (Mendoza 1975: 177). ${ }^{14}$

Romanın IV. bölümünde yazar bir monolog aracılığıyla Miranda'nın yalnızlığını ve Barselona'da hissettiği korkuyu şöyle betimler: "Biliyorum, biliyorum saygınlığın bedelini ödeyemezdim. Düşman bir şehirde yaşıyorsanız, ne bir dostunuz ne de buna kavuşma ihtimaliniz yoksa, fakirseniz ve korku ve güvensizlik içinde yaşıyorsanız; kendi gölgenizle konuşmaktan sıkılmışsanız; beş dakika içinde sessizce yemek yiyip son lokmayı yutar yutmaz restorandan çıkıyorsanız; pazarların bir çırpıda geçmesini ve iş günlerinin gelmesini ve tanıdık yüzleri görmeyi diliyorsanız; (...); işte bu durumlarda insan yarım saatlik bir sohbet için bir tabak mercimek yemeğinden vazgeçebilir" (s. 105).

\footnotetext{
13 Georg Lukács yazınsal yapıtlarda happy end yani mutlu son eğiliminin gerçekliğin nesnel aktarımına engel olduğunu belirtir (Aktaran Garrido Gallardo 1992: 68). Arı Kovanı'nın başkişisi Martín Marco'nun belirsiz sonu eseri mutlu son olmaktan uzaklaştırır. Yazarın bu tutumu eserin gerçekçilik seviyesini arttırmıştır.

${ }^{14}$ La verdad sobre el caso Savolta adlı eserden Türkçeye yapılan çeviriler makalenin yazarına aittir.
} 
Eduardo Mendoza, anti-kahraman özelliklerini kendinde bulunduran başkişisi Javier Miranda aracıllı̆̆yla söz konusu yıllarda iş bulmak için büyük şehre gelmiş ve kimseyi tanımayan bir gencin burada nasıl da yalnız ve güvensiz hissettiğini ustalıkla yansıtmıştır (Serra Martínez-Oton Sobrino 1986: 195). Miranda zayıf ve kırılgandır. O yüzden anlatı boyunca kendinden daha güçlü ve büyük şehrin kurallarını bilen bir takım kişilerin yanında yer alır. Anlatı boyunca çeşitli başarısızlıklar, zorluklar ve mutsuzluklar yaşasa da herhangi bir ideolojinin temsilcisi olmadığı için kendine hızla bir çıkış yolu bulur. Toplumun genel geçer ahlak ilkelerini umursamadığı gibi, hikâyenin bir yerinde öldürülen arkadaşı Pajarito de Soto'nun karısı Teresa'ya da derin bir aşk beslediği anlaşılır. Bu da kahramanın onurlu olma özelliğine ters düşen, ancak bir anti-kahraman için olağan sayılabilecek bir davranıştır. Miranda, arkadaşının ölümünün ardından Teresa ve çocuğuna da sahip çıkmaya cesaret edemez: "Ona ne sunabilirdim? Ben sadece maaşla yaşayan biriydim" (s. 87). Onun bu korkak yapısını en iyi aktaran cümlelerden biri daha birinci bölümde okura sunulmuştur: "Kişiliğe karşı savaşılmaz ve ben tüm savaşları kaybetmek için doğmuşum" (s. 219).

Javier Miranda'nın eski kahraman arketiplerinde rastlanmayacak bir başka davranışı da sırf ekonomik çıkarlarını ve toplumda sınıfsal yükselişi istediği için María Coral ile evlenmeyi seçmesidir (Alonso 1988: 41). Aslında hedefine bu şekilde de ulaşamaz ama eşini sevmediği okur tarafından bilinir.

Edebiyat eleştirmenleri Javier Miranda'nın kendine güveni olmayan, eylemlerinin ve kuklayı andıran konumunun da farkında olmayan, kişiliğini tam olarak bulamamış bir antikahraman olduğu fikrinde birleşirler (Alonso 1988: 44). Miranda aslında yaşadığı toplumun bir gözlemcisi ve onu okura aktaran kişi konumunda kendinden yüzyıllar öncesinde kaleme alınan Lazarillo de Tormes ile çok sayıda koşutluğa sahiptir. Daha önce söz ettiğimiz pikaresk romanın bu ünlü anti-kahramanı gibi Javier Miranda da yasalarını kabul etmediği bir toplumun gözlemcisi konumundadır. O toplum yapısına ileride bir servet kazanmak için hizmet eder; Lázaro gibi pek çok sahip değiştirir; aslında iyi bir yüreğe sahiptir ancak onursuzluk karşısında durabilecek gücü de yoktur. Karısının kendisine olan sadakatsizliği karşısında bile cesaretini toplayıp karşılık veremez. Toplumdan ve bir o kadar da sefaletten korkmaktadır. Yine de Miranda'nın anlatıcı olarak her şeyi gören ancak çoğu şeyi yorumlayamayan yapısı okurun olaylara tarafsız bir aktarım aracılığıyla tanık olmasını sağlamaktadır (Alonso 1988: 44).

SEFAD, 2017 (38): 95-110 


\section{SONUÇ}

20. yüzyıla ait romanlarda gerçekçilik yaklaşımı etkin olurken, okurlar artık romantik dönemin o kendi yaşamını riske atan cesur ve onurlu beyefendilerine rastlayamaz olmuşlardır. Toplumsal gerçekçilik akımına uygun bir biçimde betimlenen bu kişiler genellikle kendinden emin olmayan, çekingen ve toplum dışına itilmiş birer "kaybeden"dir. Kahramanlığın temel kuralı olan korkusuzluktan ya da yaşamsal risk almaktan oldukça uzak olan bu roman başkişileri çoğu zaman günü kurtarmaya çalışırken, bunu etik dişı davranışlarla yaptıkları da gözlenebilir. Anti-kahramanın klasik kahramana göre farklı özelliklere sahip oluşu İmgesel Yapısalcılığın kurucusu olan Gilbert Durand'ın da öne sürdüğü gibi edebi eserlerde karşıt bir ortam yaratmış, karşıtlıkların bulunduğu böylesi betimlemelerde de okur kahramandaki bu önemli değişimi açıkça algılayabilir olmuştur.

Anlatıdaki bu önemli değişimin temel nedeni toplumsal değişim olarak kabul edilebilir. Edebi eserlerin üretiminin toplumların içine girdiği savaş, kıtlık, ve ahlaki çöküşe koşut olarak şekillendiği gözlemlenmektedir. Bunun en belirgin örneklerinden birisi de Avrupa edebiyatında önemli bir yere sahip olan İspanyol edebiyatıdır. İspanyol toplumunun 16. ve 20. yüzyıllarda yaşadığı toplumsal değişim, işsizlik ve savaşlar söz konusu tarihsel dönemlerde roman yazınında benzer değişikliklerin gerçekleşmesine yol açmıştır. Her iki yüzyılda da kendinden önceki idealist anlatılara bir son verilmiş, gerek pikaresk gerekse 20. yüzyılın gerçekçi akımı aracılığıyla yazarlar topluma ve yöneticilere eleştiri okları yöneltilmiştir. Bu değişimin en önemli unsuru ise roman başkişilerinin geleneksel bir kahramanla karşılaştıııldığında artık etik dışı özelliklere bürünmeleridir.

Çalışmamızda ele aldığımız 16. yüzyıla ait Lazarillo de Tormes ve El Quijote romanlarının 20. yüzyıl İspanyol yazınının başyapitlarından olan La Colmena ve La verdad sobre el caso Savolta romanlarıyla benzer toplumsal eleştiri içerdiği gözlemlenmiştir.

Sonuç olarak 20. yüzyıl İspanya'sında yazılmış olan ve toplumsal betimlemeye dayanan gerçekçi romanın yine aynı ülkenin 16. yüzyıl pikaresk romanıyla kişi, konu ve üslup yönünden çok benzer özellikler taşıdığı görülür. Çöküş içindeki bir sosyal ortamı yansıtan söz konusu yüzyıllarda yazarlar anlatının kilit öğesi olarak anti-kahramanları seçmiş ve onlara toplumun kolektif sesi olarak simgesel bir değer biçmişlerdir. 


\section{SUMMARY}

This study focuses on the changes in the image of the hero portrayed in literary works, and presents these changes as a result of wars and differentiated social qualities. In this study firstly the image of the hero is explained in general terms, the contrast between hero and antihero in the light of the French structuralist Gilbert Durand's methodology is brought into focus. While doing this analysis, another major objective has been defining the effect of these changes on the composition of the Spanish novel.

Throughout this study, Spain in the 16th and 20th century Spain has been defined in detail, and the parallelism in the change of the hero's definition between these mentioned centuries has been analyzed in the light of related theories and perceptual categories.

Firstly the 16th and 20th centuries' Spanish society has been examined with all its changing characteristics. Then the most important novels of the 16th and the 20th centuries' Spanish literature Lazarillo de Tormes, El Quijote, La colmena and La verdad sobre el caso Savolta have been analyzed contrastively also with their protagonists that represent the antihero image skillfully. These protagonists are portrayed in a society which the narration criticizes severely.

It has been observed that because of similar reasons, similar consequences in Spanish society appear in the mentioned centuries. As a result of this, novelists tended to use a realistic narrative in their literary works. While doing this, they defined their protagonists as "loser" antiheroes, as fearful and antisocial ones, contrary to the tragic, epic and romantic hero images of the previous centuries. In the mentioned novels of the 16th and 20th centuries the narrative style turned to be more realistic and the protagonists behaved unethically as the 16th century's antihero archetype Lázaro. The 16th century's picaresque novel's picaro could be defined so differently than the Middle Age's Spanish hero: Cid the fearless warrior.

Starting from the 16th century, it has been nearly impossible to come across fearless heroes as it was seen in the first epic Castilian poem Mio Cid, assumed to be written in the 12th century and conserved from the Middle Ages until present.

The heroes of the previous centuries' epic poems which were the symbols of the fearlessness, adventure and action have changed especially in the 16th century's picaresque novel and similarly in the 20th century's realistic and existentialist Spanish novel. This study aims to portray the mentioned parallel development of these centuries' literary works.

SEFAD, 2017 (38): 95-110 


\section{KAYNAKÇA}

ABRAMS, Meyer Howard (1999). A Glossary of Literary Terms. Fort Worth: Harcourt B. College Publishers.

ALONSO, Santos (1988). Guías de lectura: La verdad sobre el caso Savolta. Madrid: Alhambra.

ANÓNIMO (1996). El Lazarillo de Tormes. Madrid: Alba.

BENITO LOBO, José Antonio (2000). Literatura para la vida. Madrid: Edimunen.

CAMPBELL, Joseph (2005). El héroe de las mil caras. Madrid: Fondo de Cultura Económica.

CASARIEGO, Nicolás (2000). Héroes y antihéroes en la literatura. Madrid: Anaya.

CELA, Camilo José (t.y.). Arı Kovanı. çev. Alev Güçlü. İstanbul: Can Yay.

CHEVALIER, Jean (1988). Diccionario de los simbolos. Barcelona: Herder.

FERRERAS, Juan Ignacio (1973). Introducción a una sociología de la novela española del siglo XIX. Madrid: Edicusa.

GARRIDO GALLARDO, Ángel (1992). La Teoría Literaría de György Lukács. Valencia: Amós Belinchón.

GOLDMANN, Lucien (2005). Roman Sosyolojisi. çev. Ayberk Erkay. Ankara: Birleşik Yayınlar.

GONZÁLEZ TROYANO, Alberto (1988). El Torero Héroe Literario. Madrid: Espasa-Calpe.

İLGÜREL, Mehmet (2016). Julio Cortazar'ın Öykülerinin Sembolik İmgelemi. İstanbul: Yeni İnsan Yayınevi.

JÁUREGUI LOBERA, Ignacio (2007). Conducta alimentaria y sus alteraciones en la picaresca Española. Madrid: Diaz de Santos.

KUMRULAR, Özlem (2011). "İspanyol Altın Çağı Pikaresk Romanı'nda Hırsızlar". İ̈̈ Mediterráneo Dergisi (5): 23-34.

LUKÁCS, Georg (1970). “Writer and Critic” and Other Essays. London: Merlin.

LUKÁCS, Georg (2007). Roman Kuramı. çev. Cem Soydemir. İstanbul: Metis.

MAIORINO, Giarcarlo (2003). At the Margins of the Renaissance: Lazarillo de Tormes and The Picaresque Art of Survival. Pennsylvania: The Pennsylvania State University Press.

MENDOZA, Eduardo (1975). La verdad sobre el caso Savolta. Barcelona: Seix Barral.

NORTHROP FRYE, Herman (1957). Anatomy of Criticism. New Jersey: Princeton U. Press.

PÉREZ-RASILLA BAYO, Eduardo (1990). Obras clave de la narrativa española. Madrid: Ciclo.

SERRA MARTINEZ, Elias-OTON SOBRINO, Alberto (1986). Introducción a la literatura española contemporánea a través del comentario de textos. Madrid: Edinumen.

TURNER, Harriet-LOPEZ MARTINEZ, Adelaida (2003). The Cambridge Companion to the Spanish Novel. Cambridge: Cambridge University Press.

VILLEGAS, Juan (1978). La estructura mítica del héreo en la novela del siglo XX. Barcelona: Planeta.

WELLEK, René-WARREN, Austin (1959). Teoría de la Literatura. Madrid: Gredos. 